\title{
AN ANALYSIS OF SENIOR HIGH SCHOOL STUDENTS' MATHEMATICS COMPETENCY IN THE FREE TRADE ZONE OF RIAU ISLANDS PROVINCE, INDONESIA
}

\author{
Desi Rahmatina ${ }^{1}$, Martaleli Bettiza ${ }^{2}$ \\ Raja Ali Haji Maritime University, Tanjungpinang, Indonesia
}

desirahmatina@umrah.ac.id ${ }^{1}$, mbettiza@umrah.ac.id ${ }^{2}$

First draft received: 03 May 2018 Accepted: 31 June 2018 Final proof received: 20 August 2018

\begin{abstract}
This study is intended to provide an analysis of the competency map of senior high school students in the Final National Exam (FNE) for mathematics subject in the Free Trade Zone (FTZ) of Riau Islands province. Sample was determined by examining secondary data in the form of 2014 Final National Examination (FNE) results published by the Education Assessment Center of the Ministry of Education and Culture of the Republic of Indonesia in the FTZ of Riau Islands Province, namely Batam, Bintan, and Karimun regencies. Criteria of sample determination were schools with lower Graduate Competency Standards (GCS) than the regency/city GCS, distribution of public or private schools, and distribution of school locations, with a total sample of 37 schools. The research was conducted by using descriptive statistical method to gain a description of the senior high school students' competency in mathematics subject based on their FNE scores. The results of this research can be made input and consideration for schools and government to improve the quality of education through analysis of the FNE results. The research results show that low GCS achievements were found in geometry and trigonometry topics, especially in the skills of determining position, distance, and magnitude of angles involving points, lines, and fields in solid geometry. The mean percentage of GCS mastery in the FTZ was $22.86 \%$, with Batam $26.02 \%$, Bintan $18.66 \%$, and Karimun $18.72 \%$. The result of the interview shows that the low GCS is caused by the lack of teaching media in the visual forms or simulators to build students' understanding and limited time allocated in teaching. The solution recommended to solve this problem is by applying ICT-based learning to improve students' understanding of geometry and trigonometry materials and also the use of video conferencing during mathematics teacher working group meetings.
\end{abstract}

Keywords: Mathematics; Free Trade Zone; Graduate Competency Standards

To cite this paper (in APA style):

Rahmatina, B., \& Bettiza, M. (2018). An analysis of mathematics results of senior high school national final examination in the Free Trade Zone of Riau Islands Province, Indonesia. International Journal of Education, 11(1), 27-34. doi: http://dx.doi.org/10.17509/ije.v1111.10891.

\section{INTRODUCTION}

Government Regulation of the Republic of Indonesia Number 32 Year 2013 article 68 stipulates that the National Examination is used as a basis for mapping the quality of education programs, consideration of the selection of the next level of education as well as the development and provision of assistance to educational units in an effort to improve the quality of education." Furthermore, Article 69 states that every student must take the Final National Examination at the end of school level without any cost (paid by the government), and that final national exam participants will obtain a certificate of national examination results, which is issued by the national exam organizer. Competency map identifies an individual's weaknesses and strengths. Jensen (2007) stated that mathematical competence is analytically spanned by a set of such mathematical competencies, and it is a very interesting challenge to try to come up with a suggestion for, and exemplification of, the elements of such a set. In education, assessment is a statement of a number of facts to explain a person's characteristics so that a final test is needed to evaluate these characteristics. And a final examination or summative test is a test given to students at the end of a course of study and given to assessment that is carried out for the purpose of reporting achievement at a particular time (PereraDiltz \& Moe, 2014).

For mapping in the context of developing the quality of education, schools and local governments will receive analysis of the results of the Final National Exam so as to provide an overview of the comparison of national exam results with other regions as well as comparisons at the national level. Some researchers have conducted research on mapping the quality of education through the results of the Final National Exam as conducted by Zulkardi, et al. (2011) who produced a map of high school students' competency on each difficult subject on Final National 
Examination. The map was generated using PPMP Software version 2.4. According to Luneta (2015) reported that geometry is difficult to teach as well as to learn, the majority of students did not understand of the basic concepts in geometry, students did not understand the questions and did not know what to do as a result of final grade 12 examination and most mathematics teachers do not seem to have the knowledge and instructional skills required to explain concepts in geometry.

In addition, Fabiyi (2017) surveyed 500 senior secondary school students in Ekiti State, Nigeria and recommended that the identified difficult geometry concepts in mathematics should be taught by using appropriate teachers' method of instruction and instructional materials. And the research of Pratiwi, et al. (2011) found that the factors causing low achievements among students include the level of competency tested on the Final National Examination being too difficult and students not mastering the conceptual basis and the variation of cases that may arise from the concept. The solutions offered in their research include improving teacher competence in studying curriculum, improving the teaching materials, and meeting the needs of learning facilities that support national examination.

Because there has been no research on the results of final national examination in the FTD of Riau Islands, herein we analyze the results of the Final National Examination for Senior High School in the subject of mathematics in Riau Islands or Kepri Province. Riau Islands province is an archipelagic region, where $95 \%$ of its territory comprises of an ocean with 2,408 islands. The geographical position affects the speed and accuracy of the information received by the local governments from the central government. In this research, we will study the possible factors that cause the low of GCS in mathematics and then we will formulate solutions to solve the problems.

\section{METHOD}

Qualitative approach method was used in this research to analyze the mathematics scores of senior high school students in their national exam in the FTZ. The primary data were obtained through interviews and questionnaires filled in by senior high school mathematics teachers and senior high school graduates in the FTZ, and secondary data in the forms of FNE scores published by the Center of Education Assessment (Ind. Puspendik) of the Ministry of Education and Culture of Indonesia (MoEC, 2014). Sample comprised of schools in the FTZ, senior high school graduates, and senior high school mathematics teachers in the FTZ. The senior high school graduates serve as respondents in this study to provide information about the problems experienced by them while in schools in terms of mastery of GCS. They were pre-service teachers or students of Mathematics Education Department of Maritime University Raja Ali Haji academic year $2014 / 2015$. The students were selected purposively on the basis of convenience of accessible data. These students were further selected based on their school origins, namely the schools located in the Free Trade Zones. In addition to senior high school graduates, mathematics teachers were selected as respondents to obtain information about problems, causal factors, and solutions regarding GCS problems. The schools were sampled purposively, based on the following criteria:

1. Graduate Competency Standard (GCS) is said to be problematic if the percentage GCS mastery is below that of the regional (Riau Islands Province) or the national GCS.

2. GCS of the school is said to be problematic if the percentage of GCS mastery at the school level is below the average of GCS of the FTZ.

Senior High School populations in the FTZ are shown in table 1 and 2.

Table 1. The number of senior high schools in the FTZ year 2014

\begin{tabular}{llccc}
\hline \multirow{2}{*}{ No } & City/regency & \multicolumn{2}{c}{ Senior high school } & Number of school \\
\cline { 3 - 4 } & & Public & Private & \\
\hline 1 & Batam City & 17 & 231 & 38 \\
2 & Bintan Regency & 8 & 1 & 9 \\
3 & Karimun Regency & 14 & 3 & 17 \\
\hline TOTAL & & 39 & 25 & 64 \\
\hline
\end{tabular}

Table 2. The number of school taken as sample

\begin{tabular}{|c|c|c|c|c|}
\hline \multirow[t]{2}{*}{$\mathrm{Nc}$} & \multirow[t]{2}{*}{ City/district } & \multicolumn{2}{|c|}{ Senior High School } & \multirow[t]{2}{*}{ Number of school } \\
\hline & & Public & Private & \\
\hline 1 & Batam City & 7 & 14 & 21 \\
\hline 2 & Bintan Regency & 5 & 1 & 6 \\
\hline 3 & Karimun Regency & 9 & 1 & 10 \\
\hline \multicolumn{2}{|c|}{ TOTAL } & 21 & 16 & 37 \\
\hline
\end{tabular}

Source: Education Authorities of Riau Islands Province

After sample schools were established, the teachers who taught mathematics subject were randomly extracted from the sample schools for an in-depth interview of the underlying causes of the problems 
of students' low GCS on the subject of mathematics and discussion on the solutions to the problems. In addition to interview with math subject teachers, questionnaires were distributed to senior high school graduates who passed the Final National Examination in the Free Trade Zones to get an overview of their schooling experience related to the achievement of GCS.

\section{RESULTS AND DISCUSSION \\ Competency standard of mathematics subject \\ for natural science concentration}

The mastery of GCS in each of the FTZs consisting of Batam City, Bintan Regency, and Karimun Regency is shown in Figure 2 and graduate competency standards (GCS) of the natural science concentration students are shown in table 3.

Table 3. Graduate competency standards for natural science concentration

\begin{tabular}{cl}
\hline No & \multicolumn{1}{c}{ Skills Tested } \\
\hline 1 & $\begin{array}{l}\text { Using mathematical logic for problem solving } \\
\text { Solving problems related to rules of number rank, root and logarithm, simple algebraic functions, } \\
\text { quadratic functions, exponential function and graphs, compositional functions and inverse }\end{array}$ \\
2 & $\begin{array}{l}\text { functions, systems of linear equations, equations and quadratic inequalities } \\
\text { Determining the position, distance and magnitude of the angle that involves points, lines, and } \\
\text { planes in solid geometry. }\end{array}$ \\
4 & $\begin{array}{l}\text { Using comparison, functions, equations, identities and trigonometric formulas in troubleshooting. } \\
\text { Understanding the concept of limits, derivatives and integrals of algebraic functions and }\end{array}$ \\
& $\begin{array}{l}\text { trigonometric functions, and to apply them in problem solving. } \\
\text { Processing, presenting and interpreting data, and being able to understand the rules of } \\
\text { enumeration, permutations, combinations, opportunities of occurrence and being able to apply } \\
\text { them in problem solving. }\end{array}$ \\
\hline
\end{tabular}

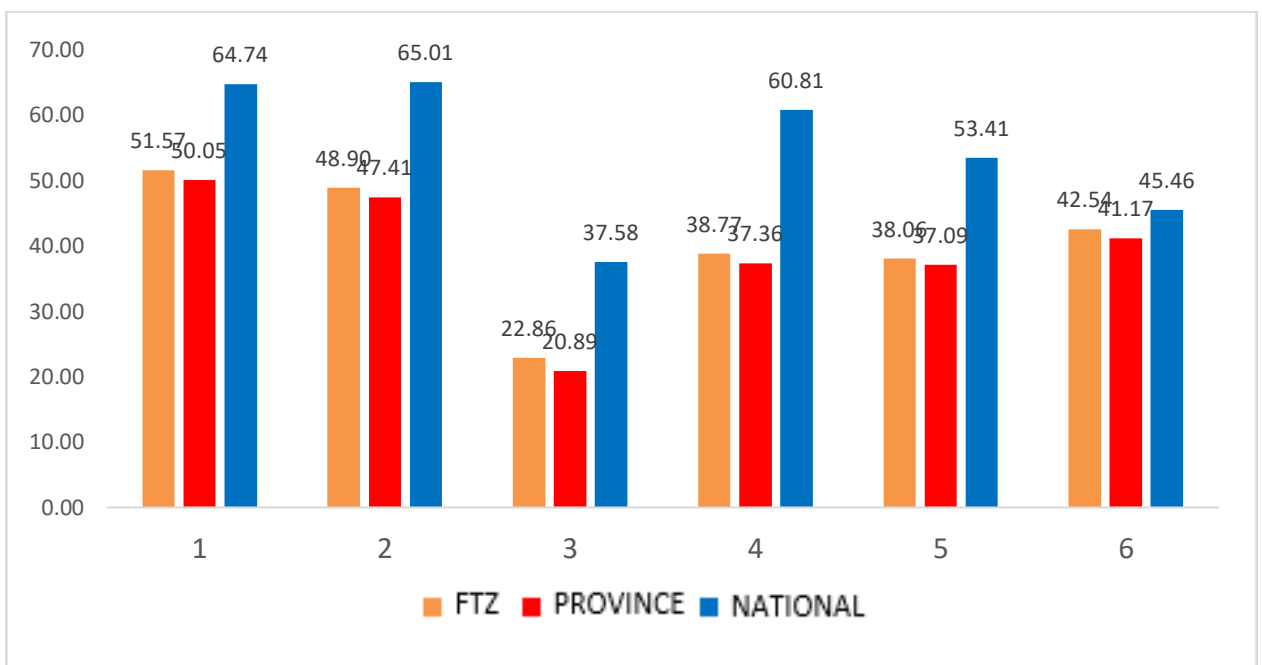

Figure 2. Achievements of GCS for students of the natural science concentration

From Figure 2, it can be seen that the achievements of GCS for mathematics in the FTZ were greater than the achievements of GCS for the same subject in the province of Riau Islands, but lower than the National GCS level.

The achievement of GCS in the FTZ compared to the achievement of GCS at the level of Riau Islands Province and the National level is shown in figure 3. The figure shows that GCS achievement in Batam exceeded the achievement of GCS of Riau
Islands province, but was still under the national GCS.

The highest percentage of understanding level for the first competence listed in GCS in the FTZ is for using mathematical logic in problem solving, namely for $58.77 \%$ (Batam City) and the lowest GCS mastery is for GCS determining position, distance, and angle which involves point, line, and field in three dimensional shapes for $18.66 \%$ (Bintan District). 


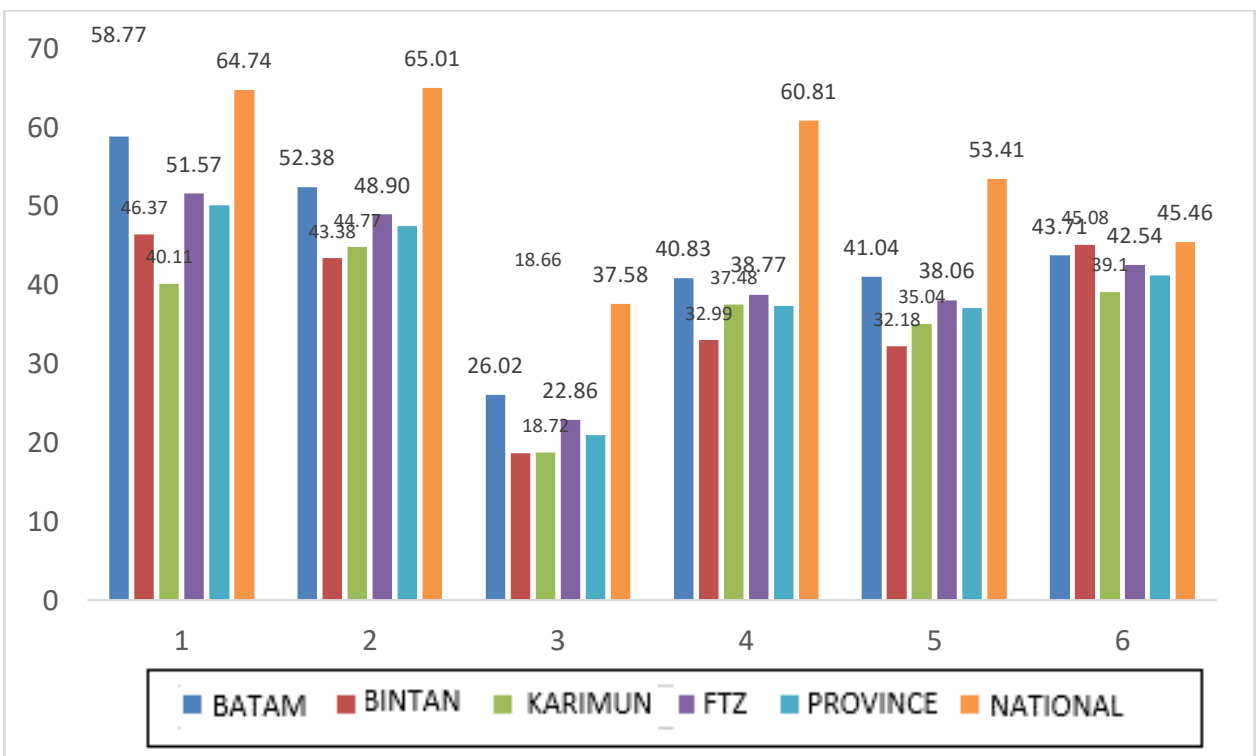

Figure 3. Comparison of senior high school GCS achievement of Natural Science concentration in the FTZ

\section{Competency standard of mathematics subject for social science concentration}

Similar to the percentage of GCS mastery for natural science concentration, Batam also gained the highest GCS for the social science concentration in the FTZ, with the highest score for the ability to understand limit function, derivative, extreme value, and integral and apply it in problem solving
$(46.82 \%)$, and the lowest percentage of $30.5 \%$ was gained by Bintan for the first competency listed in GCS, which is for using mathematical logic in problem solving. More details on the mastery of GCS for the social science concentration students are shown in in Figure 4 and table 4.

Table 4. Graduate competency standard for social science concentration

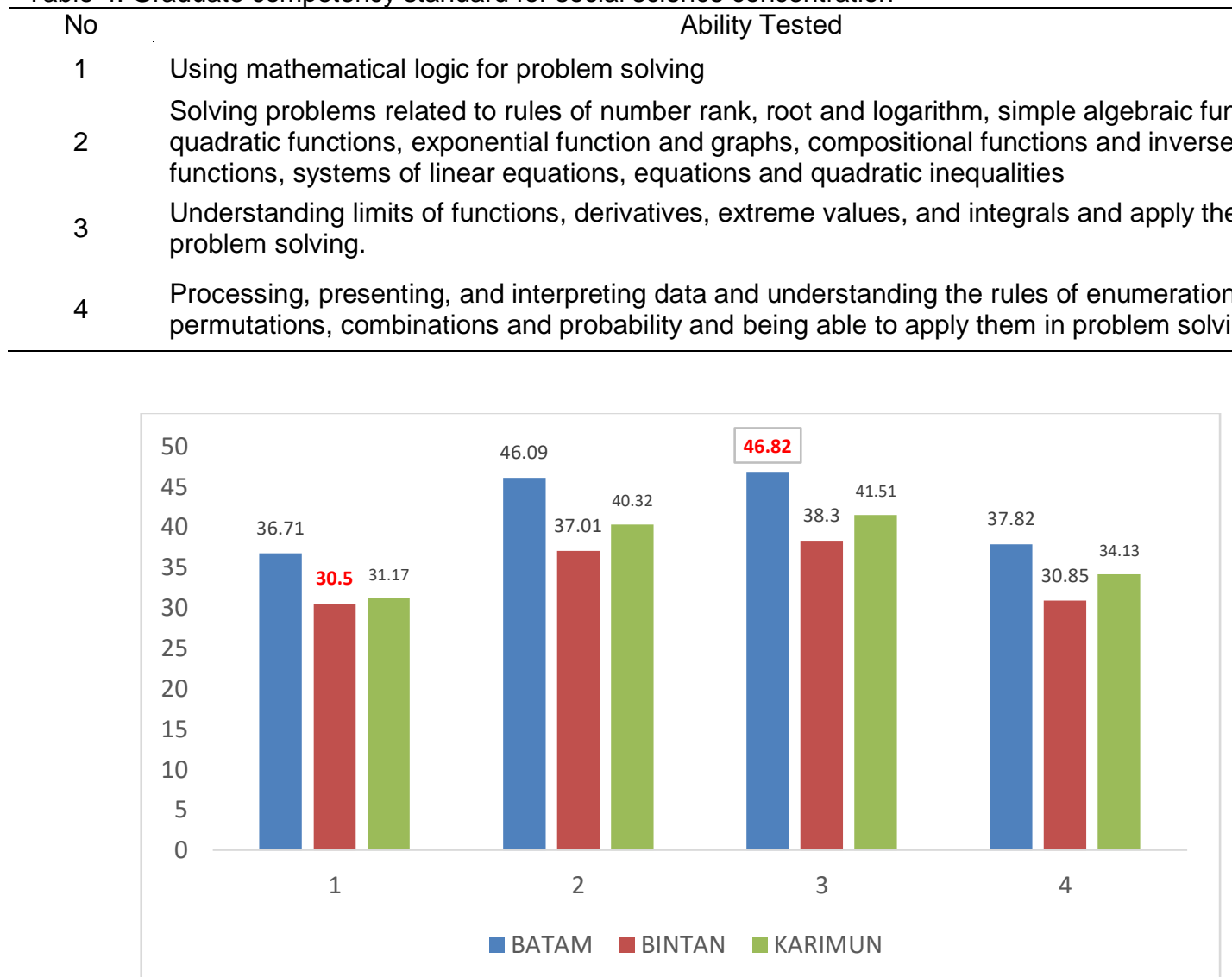

Figure 4. Achievement of Mathematics in the GCS of the social science concentration in the FTZ 


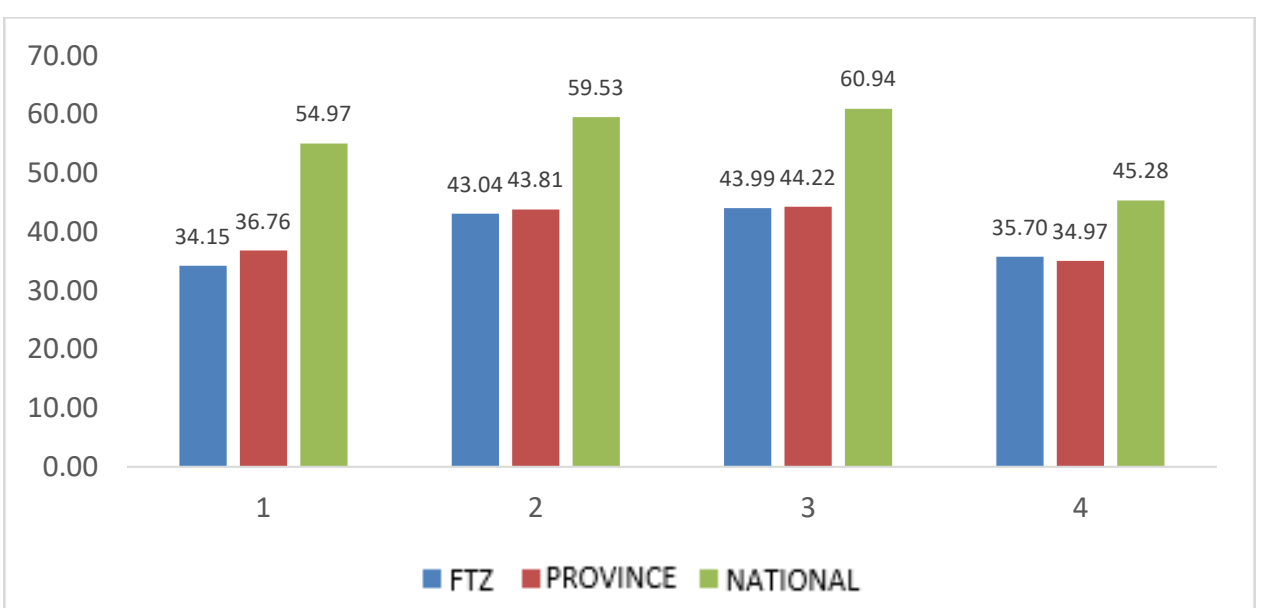

Figure 5. Comparison of mastery of Mathematics in the GCS for social science concentration

Comparison of the mathematics skills of the social science concentration students in the FTZ, as illustrated in Figure 5, indicates that the Free Trade Zones obtained higher GCS level than the regional level only for the fourth competency listed in the GCS, namely processing, presenting, and interpreting the data and understanding the rules of enumeration, permutations, combinations and probabilities and being able to apply them in solving problems (35.70\%). Meanwhile, for the regional level, the percentage was $34.97 \%$. However, GCS mastery in the FTZ and regional areas was far below the GCS at the National level.
Based on the above descriptive analysis, it can be concluded that GCS is found to be most problematic among students of natural science concentration, namely on the skills of geometry. Indeed, this particular topic has presented teachers and students with problems since 2013. Data of Riau Islands Provincial Education Department on the percentage of mastery of geometry material on mathematics problems on the 2013/2014 Final National Examination for senior high schools in the FTZ of Batam, Bintan and Karimun cities/regencies are shown in table 5 .

Table 5. Percentages of mastery on mathematical test of the 2013/2014 FNE for natural science concentration in the FTZ

\begin{tabular}{|c|c|c|c|c|c|}
\hline \multirow[t]{2}{*}{ Ability tested } & \multicolumn{3}{|c|}{ City/Regency } & \multirow{2}{*}{$\begin{array}{l}\text { Kepri } \\
\text { province }\end{array}$} & \multirow[b]{2}{*}{ National } \\
\hline & Batam & Bintan & Karimun & & \\
\hline $\begin{array}{l}\text { Students can calculate the } \\
\text { distance from point to line on a } \\
\text { geometry }\end{array}$ & 42.69 & 27.32 & 31.87 & 36.58 & 49.14 \\
\hline $\begin{array}{l}\text { Students can calculate the } \\
\text { distance from point to field in a } \\
\text { geometry }\end{array}$ & 61.46 & 22.09 & 37.68 & 49.46 & 60.07 \\
\hline
\end{tabular}

Based on data presented in table 5, the mastery of natural science concentration students on the topic of distance in solid geometry in the FTZ was below the percentage of the national level, except for Batam, where the percentage of mastery of students on the topic was $61.46 \%$, which is above the percentage of mastery nationally of $60.07 \%$.

The result of mastery of the mathematics topics in the 2014/2015 final national examination in the FTZ is shown in table 6.

Table 6. Percentages of students' mastery of mathematics problems in the 2014/2015 Final National Examination of the natural science concentration the FTZ areas

\begin{tabular}{lrrrrr}
\hline Ability tested & \multicolumn{3}{c}{ City/Regency } & \multirow{2}{*}{ Province } & \multirow{2}{*}{ National } \\
\cline { 2 - 4 } & Batam & Bintan & Karimun & & \\
\hline $\begin{array}{l}\text { Students can calculate the } \\
\text { distance from a point to a plane }\end{array}$ & 24.84 & 14.25 & 14.22 & \multirow{2}{*}{17.71} & \multirow{2}{*}{35.08} \\
\hline $\begin{array}{l}\text { Students can calculate the } \\
\text { distance from a point to field in a } \\
\text { space wake }\end{array}$ & 27.19 & 23.06 & 23.22 & 24.06 & 40.07 \\
\hline
\end{tabular}

Source: Center for Education Assessment of the MoEC

Table 6 indicates that the mastery of high school students on geometry was very low. The same is true for the percentage of mastery on the
Mathematics subjects in the National Examination for senior high school with natural science concentration for the academic year 2013/2014, in which senior high school students in Batam got a 
higher percentage of mastery of geometry material

\section{Senior High School Graduate Perceptions about Mastery of GCS}

Results on analysis of the opinions and perceptions of senior high school graduates in the FTZ areas, in this case the pre-service teachers of Mathematics Education Department of Maritime University Raja Ali Haji academic year 2014/2015 of their experience during their study in high school majoring in natural science on geometry material are shown in table 8 . The question is:

Table 8. Summary of students' learning experience of geometry concept in school in the FTZ areas High Schools in University entrance exam Learning experience at high school the FTZ

\begin{tabular}{ll}
\hline Batam & $\begin{array}{l}\text { SNMPTN (National } \\
\text { Higher Education } \\
\text { Entrance Exam based on } \\
\text { academic achievements) }\end{array}$ \\
& \\
\hline Bintan & SBMPTN (Joint Entrance \\
& Test for State \\
Universities)
\end{tabular}

Karimun SBMPTN

Discussion about the distance between a point, a line and a field on a plane was taught at the end of the semester, and the teacher did not explain in detail because of time constraints with the School Exam. Obstacles encountered include the learning process that did not use media or supporting software, so it was difficult to imagine the object in question. In order to easily understand the concept, the explanation of solid geometry must use media or supporting application

The media used in learning geometry were only the ruler and some common stationery. The teacher explained in one direction regardless of whether the student understood it or not, and without allowing dialogue or questions.

During discussion on the three-dimensional geometry, I did at the regional level.

Have you ever studied the topic of geometric distance in your school? If yes, tell us about the classroom learning experience.

The senior high school graduates in the FTZ responded that they have learned about the topic of geometric distance in senior high school. Table 7 presents a background description of the respondents, and their perceptions and experiences are summarized in table 8. not have a sufficient and precise understanding of distance in geometry. The teacher explained by using the cube, beam, and other three-dimensional objects, sometimes using LCD Projector. The method used was the lecturing method, no group discussion. I had difficulties to imagine threedimensional objects when dealing with the questions

mathematics in school. The authors went on

Based on the analysis in table 8 , it can be concluded that the pre-service teachers (students majoring in mathematics education of the fourth semester IV) who just completed high school education in the academic year 2013/2014 lack understanding of basic materials on solid geometry, and had difficulty in reasoning and imagining the concept of distance in space. The lack of understanding and the low ability of students in working on problems related to solid geometry require a problem-solving model. There were even students who say that they skipped questions on geometry in the Final National Exam or SBMPTN, especially on the topic of the distance between points, a point and a line, and between lines. Results of mastery of senior high school students and the opinions of high school graduate about the topic of geometry as shown in the tables above become the reason why the authors are interested in examining more about the problems in teaching materials on geometry as part of the subject of reviewing the learning model and the teaching method used by teachers, the preparation and formulation of indicators of achievement of Lesson Plan, and the level of students' understanding of the topic on geometry. The research was conducted in the FTZ areas, as special economic areas, to find a suitable model in improving students' understanding of solid geometry in the FTZ regions.

\section{Perceptions of Mathematics Teachers of the Problems of GCS Mastery}

Respondents in this study, in addition to high school graduates, also included math teachers in schools in the FTZ regions. The results of questionnaires and interviews with teachers are expected to provide an overview of the problem, the causes of the problem, and alternative problem solutions, especially on GCS, particularly on the topic of geometry. The results of questionnaires about the mastery of GCS distributed to the math teachers in the natural science concentration the FTZ are shown in table 9. 
Table 9. Summary of mathematics teacher's perceptions of the mastery of Mathematics of natural science concentration students.

\begin{tabular}{|c|c|c|c|}
\hline Competency tested & Problem & $\begin{array}{l}\text { Problem-causing } \\
\text { Factors }\end{array}$ & Alternative Solutions \\
\hline $\begin{array}{l}\text { Determining the } \\
\text { position, distance, and } \\
\text { magnitude of an angle } \\
\text { that involves points, } \\
\text { lines, and planes in } \\
\text { space. }\end{array}$ & $\begin{array}{l}\text { - Students have } \\
\text { difficulty imagining } \\
\text { the shape of the } \\
\text { solid geometry to be } \\
\text { solved, looking for } \\
\text { distance and the } \\
\text { large angles, points, } \\
\text { lines, and planes in } \\
\text { three dimensional } \\
\text { shapes. }\end{array}$ & $\begin{array}{l}\text { - Lack of learning } \\
\text { media to make it } \\
\text { easier for students } \\
\text { to understand the } \\
\text { concept to } \\
\text { determine distance } \\
\text { and point of } \\
\text { angles, lines and } \\
\text { space in three- } \\
\text { dimensional } \\
\text { shapes. } \\
\text { Three } \\
\text { dimensional/solid } \\
\text { geometry is a } \\
\text { learning material } \\
\text { that requires a } \\
\text { means to visualize } \\
\text { the shapes. }\end{array}$ & $\begin{array}{l}\text { - Using learning } \\
\text { software such as } \\
\text { wingeom and } \\
\text { geogebra. }\end{array}$ \\
\hline
\end{tabular}

Interviews with high school math teachers in the FTZ gave results on a number of external factors as the causes of the low achievement of senior high school students' GCS in the FTZ regions. First is the low participation of students in completing tasks given by teachers and the large number of students skipping or doing homework at school. As a result, students are not sufficiently trained to solve math problems, thereby making it more difficult for students to work on the Final National Exam problems.

Second is students' low attendance. This is caused by some students helping their parents in earning money to meet family needs, especially with students in Bintan and Karimun areas who generally have parents who work as fishermen. At harvest time, the senior high school students also help their parents, making them skip school. This low attendance affects the ability of students in mastering mathematics lessons, especially if the fish harvest time approaches the Final National Exam time.

Third is a lack of school facilities to support the achievements of GCS. Some schools do not have a computer lab. As a result, students are not introduced to the use of mathematics learning applications, especially for the achievement of GCS geometry. Presenting the material on geometry visually will facilitate students' understanding.

Fourth is teachers' lack of mastery of appropriate learning methods to create active, creative, effective and fun learning). Fifth is students' low enthusiasm and willingness to perform tasks, as indicated by students not making their homework. As a result, it is difficult for teachers difficult to measure the level of students' ability in mathematics.

Sixth, teachers find it difficult to judge students' ability from a given task because most tasks are solved by working with other students, not individually.
Seventh, the geographical position of Riau Islands Province as an archipelagic area causes teachers to experience obstacles in attending Mathematics Teacher Working Group (Ind. MGMP) activities due to the considerable distance perpetuated by the lack of public transportation and the requirement to cross the seas. The participation of the teachers in the subject teachers' forum is very important to get the latest information on teaching materials and teaching methods. In the teachers' forum, discussion on mathematics teaching problems in senior high school is often held. The lack of teachers participating actively in the subject teachers' forum can lower the quality of teaching.

The results of the study support the research conducted by Zulkardi (2011), reporting that one of the factors that cause students' lack of mastery of mathematics in the senior high school Final National Examination is the lack of opportunities or forums for mathematics teachers, such as the Indonesian MGMP, for sharing and collaboration to make preparation for teaching and also to practice solving questions appropriate for all levels. However, in contrast to the present research results, the research by Rasto, et al. (2011) found that the factors causing the low achievement of GCS of senior high school students in mathematics subjects was teachers' lack of knowledge about learning models and strategies in teaching.

As for the sub-topic of mathematics subject in which students had low mastery, particularly on solid geometry, the results of research conducted by Kaniawati and Ramalis (2012) instead revealed that the students had low cognitive ability to determine and resolve, especially the topics of Algebra, Equality and inequality, and Trigonometry.

\section{The solutions}

Based on the findings in the research, four solutions are formulated and offered to solve the problem of low GSC mastery among senior high school 
students in the FTZ. First, regarding the low rate of students' attendance and the high rate of students skipping homework, it is important to provide understanding to parents to pay attention to their children's learning activities at home and do their homework. At least, parents should always remind their children to review the lessons at home. Second, the teachers who cannot attend the teacher's forum can ask for discussion materials from their colleagues who were present. Third, subject teachers' forum activities can be held through video conferencing to anticipate teachers who have problems with long distance and weather constraints that they fail to attend the meeting. Fourth, schools should improve school facilities and infrastructure to support the achievement of GCS, such as providing a sufficient number of mathematics books and providing computer labs to implement ICT-based learning process. In line with the geographical position of the FTZ region which is close to Asian countries (Malaysia and Singapore), the use of ICT in learning can prepare of the student to work successfully in the 21 st century world.

\section{CONCLUSIONS AND \\ RECOMMEDATIONS}

The findings regarding high school students' lack of mastery of the concept of geometry as the topic that has the lowest GCS mastery in the FTZ necessitates a problem-solving model for the realization of active, creative, effective and fun learning. Students' competence in mathematics subject can be improved provided that there are integrated efforts from the school, teacher, and parents. Schools can improve the learning facilities to support ICT-based teaching and learning that can accommodate appropriate learning methods and media for the teaching of solid geometry which as is admitted by students requires high visualization.

Teachers should increase their active participation in the teacher's forum in order to improve their knowledge and skills of teaching and learning. Teachers should also turn to the technology of video conferencing to tackle with distance issue in attending the forums.

Finally, parents play an equally important role in encouraging their children to attend schools regularly, do homework, and pay more attention to their learning at home and in schools.

\section{ACKNOWLEDGMENT}

The authors would like to thank the Directorate of Research and Community Service, Directorate General for Research and Development at the Ministry of Research, Technology and Higher Education that has supported this research through the Competitive Research Grant scheme in 2016.

\section{REFERENCES}

Allen, G. D., \& Ross, A. (2017). Pedagogy and content in middle and high school mathematics.. Netherlands: Sense Publisher.

Dwiatmoko, A. I. G., Gunawan, R., \& Rosa, P. H. P. (2015). Statistical Analysis of National Exam Score Results of Senior High Schools in
Yogyakarta Special Region. Jurnal IImiah Widya Teknik. 14 (2), 1-7.

Fabiyi, T. R. (2017). Geometry concepts in mathematics perceived difficult to learn by senior secondary school students in Ekiti State, Nigeria. IOSR Journal of Research \& Method in Education (IOSRJRME), 07(01), 83-90. https://doi.org/10.9790/73880701018390

Jensen, T. H. (2007). Assessing mathematical modelling competency. Mathematical Modelling (ICTMA12) Education, Engineering and Economics, 141-148. https://doi.org/http://dx.doi.org/10.1533/9780 857099419.3.141

Kaniawati, I., \& Ramalis, T. R. (2012). Analysis of map competence results of senior high school national examination in West Java (Survey in Bandung and Cimahi City). Jurnal Pengajaran MIPA, 17(1), 77-85.

Li, Y., \& Lappan, G. (2014). Mathematics curriculum in school education. New York London: Springer Dordrecht Heidelberg.

Luneta, K. (2015). Understanding students' misconceptions: An analysis of final grade 12 examination questions in geometry. Pythagoras, 36(1), 1-11. https://doi.org/10.4102/pythagoras.v36i1.261

Perera-Diltz, D., \& Moe, J. (2014). Formative and Summative Assessment in Online Education. Journal of Research In Innovative Teaching, 7(12), 130-142.

Pratiwi, Y, et al. (2011). Mapping and Development of education quality in Ponorogo and Trenggalek districts. Indonesia Science \& Technology Digital Library. University of Malang.

Puspendik Kemdikbud. National Examination Results Report. 2014.

Rasto, et al. (2011). Analysis of National Exam Results Competency Map and the Model for Developing the Quality of High School Education in West Java. Article Research Results of the Indonesian Education University.

Rosa, P. H. P., \& Dwiatomoko, I. (2017). Quality mapping of senior high schools based on national exam scores and absorption level: A Case study at Special Region of Yogyakarta. Proceedings of the 2017 International Conference on Computer Science and Artificial Intelligence. 253-258.

Santyasa, I. W.. (2009). Development of research methods and module of development theory. Paper presented in the training for teachers of kindergarten, elementary school, junior high school, high school and vocational school in Nusa Penida Subdistrict, Klungkung District, 12-14 January 2009.

Zukardi (2012). Model of quality improvement of senior high school education in Prabumulih City, Ogan llir Regency and Ogan Komering Ilir Regency. Proceedings of the National Seminar on Research Results. Sriwijaya University. 